\title{
Scarp retreat versus pinned drainage divide in the formation of the Drakensberg escarpment, southern Africa
}

\author{
Andy Moore \\ AMPAL (Pty) Limited, Box 802, Gaborone, Botswana \\ email: andy.moore@info.bw \\ Tom Blenkinsop \\ School of Earth Sciences, James Cook University, Townsville, QLD 4811, Australia \\ email: thomas.blenkinsop@jcu.edu.au \\ (ㄷ) 2006 December Geological Society of South Africa
}

\begin{abstract}
The dramatic escarpment bounding the Drakensberg-Maluti mountainland has long been regarded as a classic example of a topographic feature formed by scarp retreat processes. However, this view has recently been challenged on the basis of apatite fission track (AFT) and cosmogenic isotope data, which are argued to be inconsistent with a uniform rate of scarp retreat from the original position of continental break-up. It was suggested rather, that the evolution and present position of the escarpment was controlled primarily by a pre-existing inland drainage divide. Numeric surface process models have been used to support this interpretation, although these rely on a large number of unconstrained variables, and thus do not provide unique solutions.

However, several lines of direct geological field evidence support the scarp retreat model for the evolution of the Drakensberg escarpment. The Drakensberg-Maluti Mountains in southern Africa are formed by a $\sim 1000 \mathrm{~m}$ thick sequence of Karoo basalts, capping Karoo sediments. This mountainland has an approximately rectangular shape, surrounded by orthogonal escarpments, except in the southwest, where it is dissected by the deeply incised Orange River. In detail, these marginal scarps are everywhere double topographic features, reflecting two resistant layers that form prominent cliffs: the thick upper basalt flows, and the Clarens Formation sandstone at the base to the lava sequence. Moreover, in the Drakensberg-Maluti example, the presence of inland-facing escarpments reveals that escarpment formation is not exclusively related to processes that occur at or adjacent to the site of continental break-up. These direct geomorphological and geological observations demonstrate that resistant units are the dominant influence in escarpment formation. Headward retreat of large waterfalls on major rivers over considerable distances (10-100 km) provides clear field evidence that scarps formed by resistant lithologies will not invariably degrade as a result of the existence of an inland drainage divide, as has been argued on the basis of surface process modelling.

Several complementary factors provide a ready explanation for apparent inconsistencies in the scarp retreat model that were identified from the AFT and cosmogenic isotope studies. The Drakensberg-Maluti mountains are surrounded by a dense network of dolerite dykes that were contemporary with, and supplied, the Karoo basalts. The massive lava flows capping the modern escarpment therefore probably originally extended at least to the edge of the dyke network. The advance inland of an erosion front, initiated by continental break-up, would have slowed dramatically where such massive lava flows were encountered. Tectonic processes, climate changes, and possibly plant evolution may have compounded this decrease in erosion rates. Although these latter factors are not readily quantified, they were probably subordinate to the dominant lithological control that we invoke. Escarpments may thus form and persist over long periods, extending from the time of continental break-up to the present, independently of inland drainage divides. These field observations must be taken into consideration when assigning values to the numerous unconstrained variables used in surface process models.
\end{abstract}

\section{Introduction}

Southern Africa has long held central stage in the debate surrounding the evolution of erosional land surfaces. A key player in this controversy was Lester King, who argued that the landscape of the African sub-continent is the product of multiple erosion cycles (e.g. King, 1963; 1972). He envisaged that scarp retreat is the dominant control in the planation of successive land surfaces, and that episodic continental uplift provided the mechanism for initiating new erosion cycles (King, 1955). The dramatic basalt-capped section of the Great Escarpment that forms the Drakensberg-Maluti mountainland (Maluti is the name given to the mountainland in Lesotho), overlooking the eastern seaboard of southern Africa, served as the type area for
King's scarp retreat model. Subsequent studies by Ollier and Marker (1985) and Partridge and Maud (1987) endorsed the view that the Drakensberg section of the Great Escarpment formed as a result of scarp retreat.

There has been a recent upsurge in interest in the morphological development of escarpments associated with passive continental margins, and their implications for landscape evolution (e.g. Van der Beek and Braun, 1999; Cockburn et al., 2000; Matmon et al., 2002). The Drakensberg section (Figure 1) of the Great Escarpment of southern Africa has once again been central to this debate, with criticism being levelled at both King's model for the evolution of multi-cyclic erosion surfaces in southern Africa, and the role of scarp 
retreat in the evolution of the Drakensberg escarpment. This criticism has been based on the following lines of evidence:

1. Apatite fission track (AFT) thermochronology of samples from a borehole at Swartberg, $30 \mathrm{~km}$ seaward of the Drakensberg, was interpreted to indicate an episode of accelerated erosion between $\sim 91$ to $69 \mathrm{Ma}$ (Brown et al., 2002). This cannot be explained by models that require uniform rates of scarp retreat, commencing near the present coastline (located approximately $150 \mathrm{~km}$ to the east), at approximately $130 \mathrm{Ma}$. Partridge (1998) noted that the apparent marked decrease in erosion rates since the midCretaceous could be linked to the trend towards more arid conditions in southern Africa during the Tertiary (de Wit, 1999). However, Van der Beek et al. (2002) questioned "how a change from a tropical Cretaceous to a humid subtropical Cenozoic climate would have slowed down the processes leading to escarpment retreat by an order of magnitude", and similar doubts were expressed by Brown et al. (2002).

2. Direct estimates of recent (past $10^{3}$ to $10^{6}$ years) Drakensberg scarp retreat rates, using cosmogenic isotopes, are an order of magnitude too low if it is assumed that the scarp has migrated from an original position close to the coast at a uniform rate since formation of the continental margin at approximately $130 \mathrm{Ma}$ (Fleming et al., 1999).

3. Theoretical modelling suggests that a drainage divide may have existed in the vicinity of the present-day Drakensberg escarpment at the time of formation of the modern east coast (Brown et al., 2002). However, these authors note that this model ignores the possible effect of rift-flank uplift associated with continental break-up and associated volcanic activity.

4. Numerical surface process models suggested that any pre-existing scarp on the coastal side of this hypothetical inland drainage divide would rapidly degrade over a timeframe of some $10 \mathrm{Myr}$, and a new escarpment would develop at the position of the inland drainage divide (van der Beek et al., 2002). Thereafter, it was concluded, very limited (10 to $15 \mathrm{~km}$ ) retreat of the escarpment would have occurred (Fleming, 1999; Brown et al., 2002; van der Beek et al., 2002).

5. Numerical surface process modelling carried out by Gilchrist and Summerfield (1990; 1991) demonstrated that formation of the coastal plain by scarp retreat would result in continuous isostatic adjustment, rather than the episodic uplifts envisaged by King (1955) to initiate new erosion cycles. Gilchrist and Summerfield (1991) suggested that in the absence of a suitable mechanism to account for pulsed continental uplift, the field evidence for the existence of multi-cyclic erosion surfaces should be critically reviewed.

Based on such lines of evidence, Fleming et al. (1999), Brown et al. (2002) and van der Beek et al. (2002)

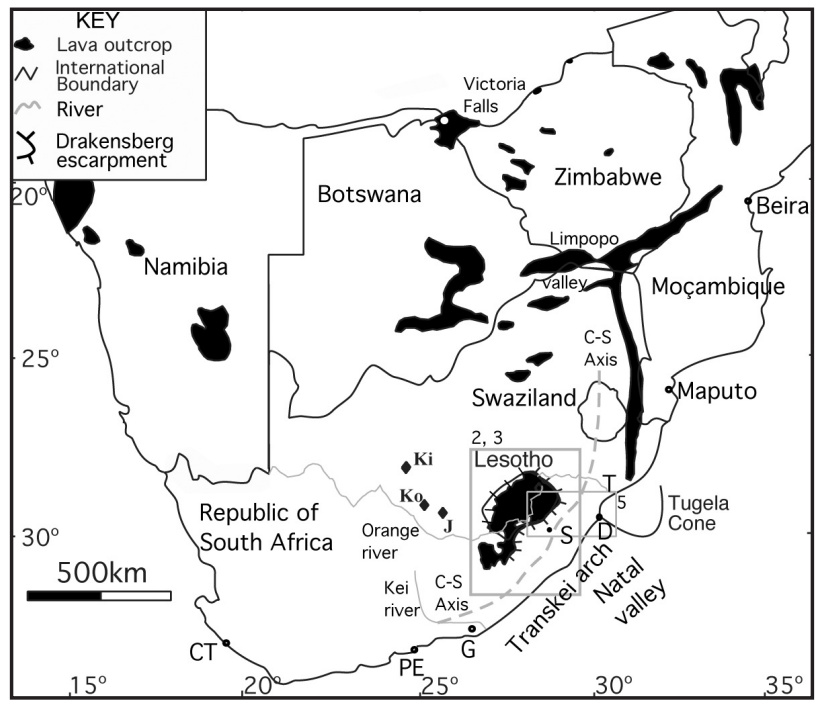

Figure 1. Distribution of exposed Karoo lavas and location map for features in southern Africa referred to in the text. Based on Dingle et al. (1983), Partridge (1998), and Moore and Blenkinsop (2002). CT - Cape Town, C-S axis - Ciskei-Swaziland axis, D - Durban, G - Grahamstown, PE - Port Elizabeth, S - Swartberg borehole, $\mathrm{T}$ = Tugela river. Numbered grey rectangles show location of Figures 2, 3 , and 5. Karoo basalt xenoliths are found in the Jagersfontein ( $\mathrm{J}$ ), Koffiefontein (Ko) and Kimberly (Ki) kimberlite pipes (Hawthorne 1975), 200 to $300 \mathrm{~km}$ west of the main Drakensberg basalt outcrop, and 80 to $100 \mathrm{~km}$ to the west of the dyke network surrounding the basalts.

therefore concluded that the evolution of the Drakensberg escarpment was controlled primarily by a pre-existing drainage divide inland of the coastal margin which formed as a result of continental break-up, rather than by scarp retreat as proposed by King (1963; 1972), Ollier and Marker (1985) and Partridge and Maud (1987).

In the present study digital elevation data, direct field observations, and compiled geological maps are presented to develop an understanding of the evolution of the Drakensberg escarpment and in particular whether an inland drainage divide will necessarily degrade a scarp formed by continental break-up. These observations are can be used to place minimum values on the critical, but unconstrained "erodability" constant $\left(\mathrm{L}_{\mathrm{f}}\right.$ ) ( $c f$. Braun and Sambridge, 1997; van der Beek and Braun, 1998; 1999) used in theoretical numerical surface modelling calculations as a measure of the resistance to erosion of different rock types. $\mathrm{L}_{\mathrm{f}}$ is a length scale that relates the evolution of topography to mass flux in a diffusional characterization of erosion - in essence, the resistance of different rock units to erosion.

\section{Observations of geologic and geomorphological features of scarps in southern Africa, with particular emphasis on the Drakensberg escarpment}

Figure 2a illustrates a Digital Elevation Model (DEM) (derived from the GTOPO $1 \mathrm{~km}$ global topographic data). Figure 3 illustrates the major geological units in 


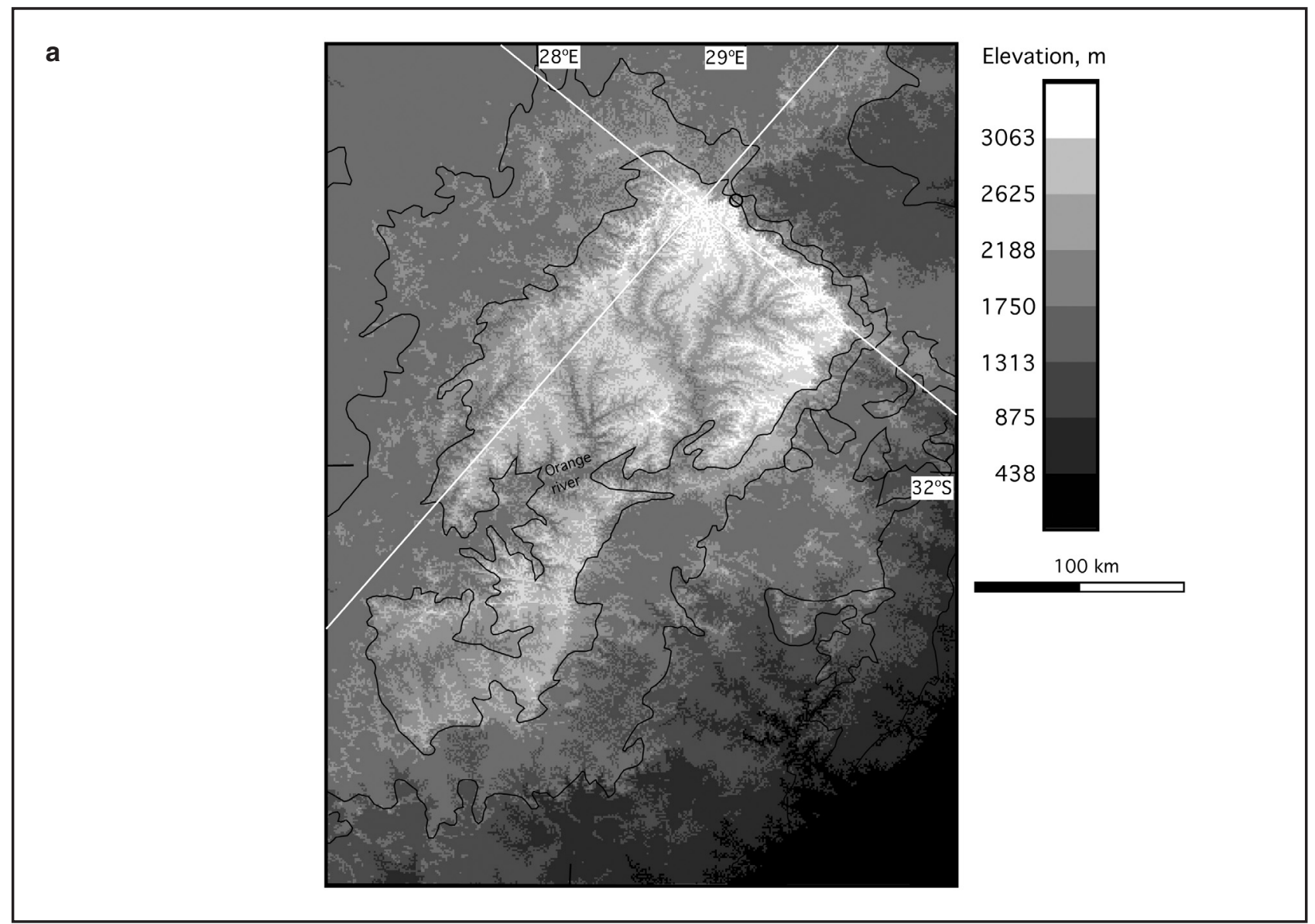

Figure 2. (a) Digital elevation model of the Drakensberg-Maluti mountains (based on GTOPO 1 km global topographic data: http://edc.usgs.gov/products/elevation/gtopo30/gtopo30.html). Contour interval of $438 \mathrm{~m}$ chosen to highlight the escarpment. White lines show topographic profiles in Figure 1b; black boundaries are the geological boundaries shown on Figure 3. Circle shows the Amphitheatre in the Royal Natal park.

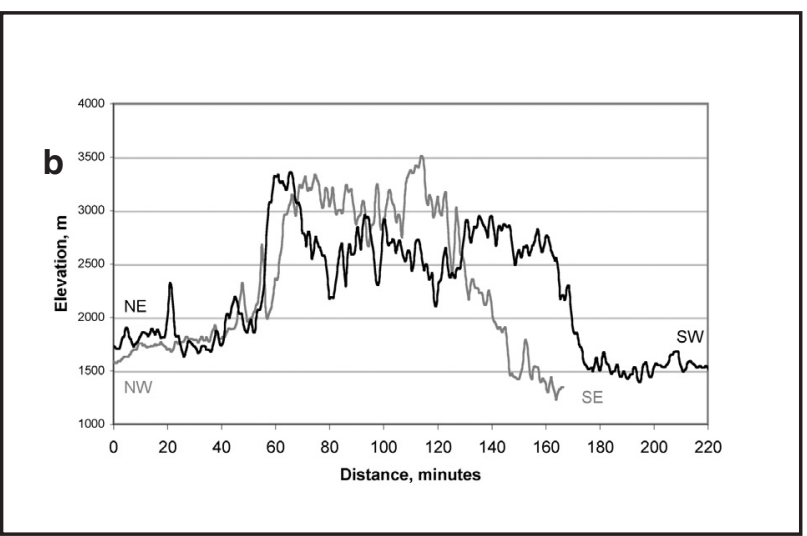

Figure 2. (b) Topographic profiles along northeast to southwesterly (black) and northwest to southeasterly (grey) profiles shown in Figure 1a.

the area covered by Figure 2a. A first-order observation is that the Drakensberg-Maluti mountains are not characterized by a single seaward escarpment (Figure 2). Rather, with the exception of the deeply incised Orange river valley, they are everywhere bounded by escarpments. In fact the shape of the DrakensbergMaluti mountains, which is reflected by the escarpments that surround them, is broadly rectangular, except for an opening to the southwest through which the Orange river flows (Figures 1 and 2a). Thus, major escarpments, approximately $200 \mathrm{~km}$ long and trending northeast to southwest flank the mountains to the southeast and northwest, while a narrower escarpment approximately $120 \mathrm{~km}$ long trends almost perpendicular along the northeastern margin of the mountains (Figure 2a).

In detail these escarpments are all compound, as illustrated by the coast-facing Amphitheatre in the Royal Natal Park (Figure 4a). The dramatic upper cliffs of the Amphitheatre are comprised of a number of massive lava flows, several tens of metres in thickness, with well-developed vertical joint sets. Below the cliffs of the amphitheatre are thin-bedded lava flows. Their brecciated upper and lower surfaces act as aquifers, and the water flow enhances chemical breakdown of these thin-bedded units. They are consequently more readily eroded than the massive flows and as a result, form rounded grassy slopes.

The Drakensberg basalts rest on the cliffs formed by the Clarens Formation. The latter is comprised of an upper massive, fine-grained sandstone, in part aeolian in origin, overlying a more argillaceous, and thus more readily eroded base (Visser, 1989). This frequently results in spectacular overhangs, which gave the unit 


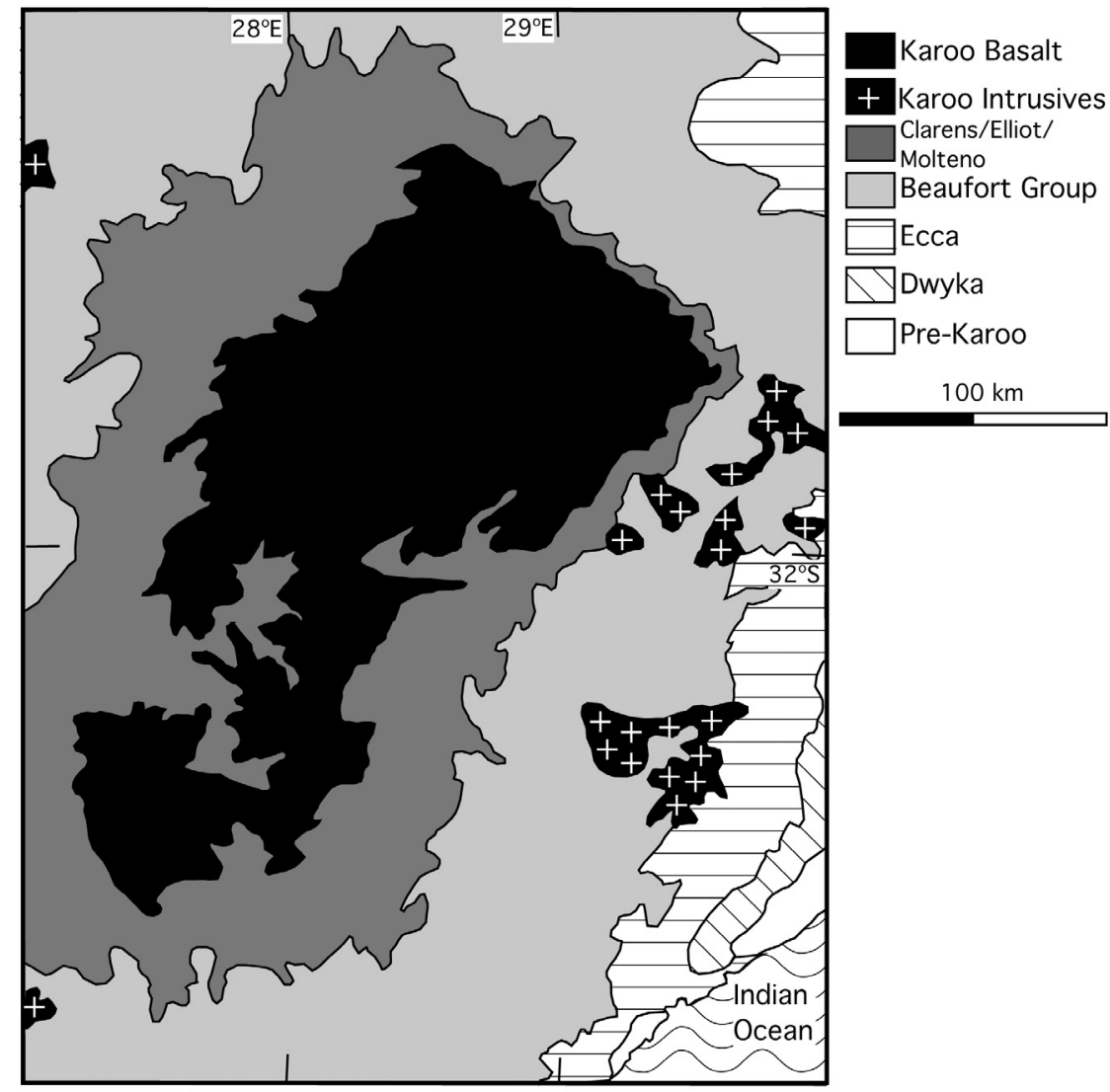

Figure 3. Major geological units of the Drakensberg-Maluti mountains and surroundings. Based on Council for Geoscience (1997).

its former name of the Cave Sandstone - and provided the focus for some of the world's most spectacular stone age rock art. Rather than a single escarpment, the Drakensberg is thus a double (Basalt-Clarens Formation) scarp, surrounding the Drakensberg-Maluti mountainland except to the southwest.

A dense dyke network has cut the entire thickness of the lava and sediment pile (Dempster and Richard, 1973), and also surrounds the present-day outcrop of the lavas. Dolerite dykes to the east of the Drakensberg form a dense boxwork within a zone extending some $60 \mathrm{~km}$ coastward of the modern escarpment (Figure 5). Geochemical studies show that the compositions of the dykes intruding and marginal to the Drakensberg lavas can be matched with those of the individual flows (Marsh et al., 1997).

The dyke boxwork recognized to the east of the Drakensberg escarpment completely surrounds the Drakensberg volcanic pile, at a similar distance to that illustrated in Figure 5 (Council for Geoscience, 1997). The concentration of dykes surrounding the Drakensberg mountainland therefore reflects an important focus of magma supply and thus volcanic activity. A less dense network of dykes, associated with abundant sills, are found several hundreds of kilometres distant in all directions from the dense dyke box work (e.g. Figure 5; Council for Geoscience, 1997). The sills to the east of the Drakensberg are in some instances several tens of metres thick, and form prominent scarps, which are reflected in inflections in east-draining rivers (van der Beek, et al. 2002). Karoo basalt xenoliths are found in the Jagersfontein, Koffiefontein and Kimberly kimberlite pipes (Hawthorne 1975), 200 to $300 \mathrm{~km}$ west of the main Drakensberg basalt outcrop, and 80 to $100 \mathrm{~km}$ to the west of the dyke network surrounding the basalts (Figure 1). This evidence shows that the Karoo lavas formerly covered a much larger area than the present-day outcrop.

Massive Karoo-age lavas form prominent cliffs over a wide geographic area of southern Africa (Figure 1), characterized by a large range in rainfall. Thus, the seaward-facing scarp of the Drakensberg is located in an area of high rainfall ( $>1000 \mathrm{~mm}$, Fullard and Darby, 1974). Rainfall is markedly lower (500 to $1000 \mathrm{~mm}$ ) on the western (inland) margin of the Drakensberg-Maluti mountains, where both massive lava flows and sandstones of the Clarens Formation form prominent scarps. The Tafelberg in northern Namibia, in the west of the sub-continent, provides an example of a scarpbound Karoo-age volcanic pile in an arid region (rainfall $<250 \mathrm{~mm}$ ), although the capping lavas in this instance are quartz latites, rather than tholeiites (Erlank et al., 1984). There are also abundant and widespread examples in southern Africa of scarps formed by thick Karoo age dolerite sills (Figure 4b), which are chemically similar to the Drakensberg tholeiite lavas. 
These are often responsible for the characteristic "koppie" topography of the central arid Karoo region of South Africa (Wellington, 1955; King, 1963), essentially miniature versions of the Drakensberg, with scarps on all sides. As is the case with the massive basalt lava flows, these thick sills commonly display prominent vertical joint sets.

Lithological equivalents of the Clarens Formation occur in the Limpopo valley (rainfall 250 to $350 \mathrm{~mm}$ ), some $750 \mathrm{~km}$ to the north of the Drakensberg, in eastern
Botswana (rainfall 400 to $500 \mathrm{~mm}$ ), and also in northwest Namibia, in the extreme west of southern Africa (rainfall $<250 \mathrm{~mm}$ ). In all localities, this lithological unit stands out as prominent cliffs.

The southern African landscape is characterized by widespread spectacular scarps formed by a variety of other resistant lithologies - particularly quartzites and dolomites - within the horizontal or mildly deformed platform sequences, ranging from Archean to Proterozoic in age, that cover much of the sub-continent.

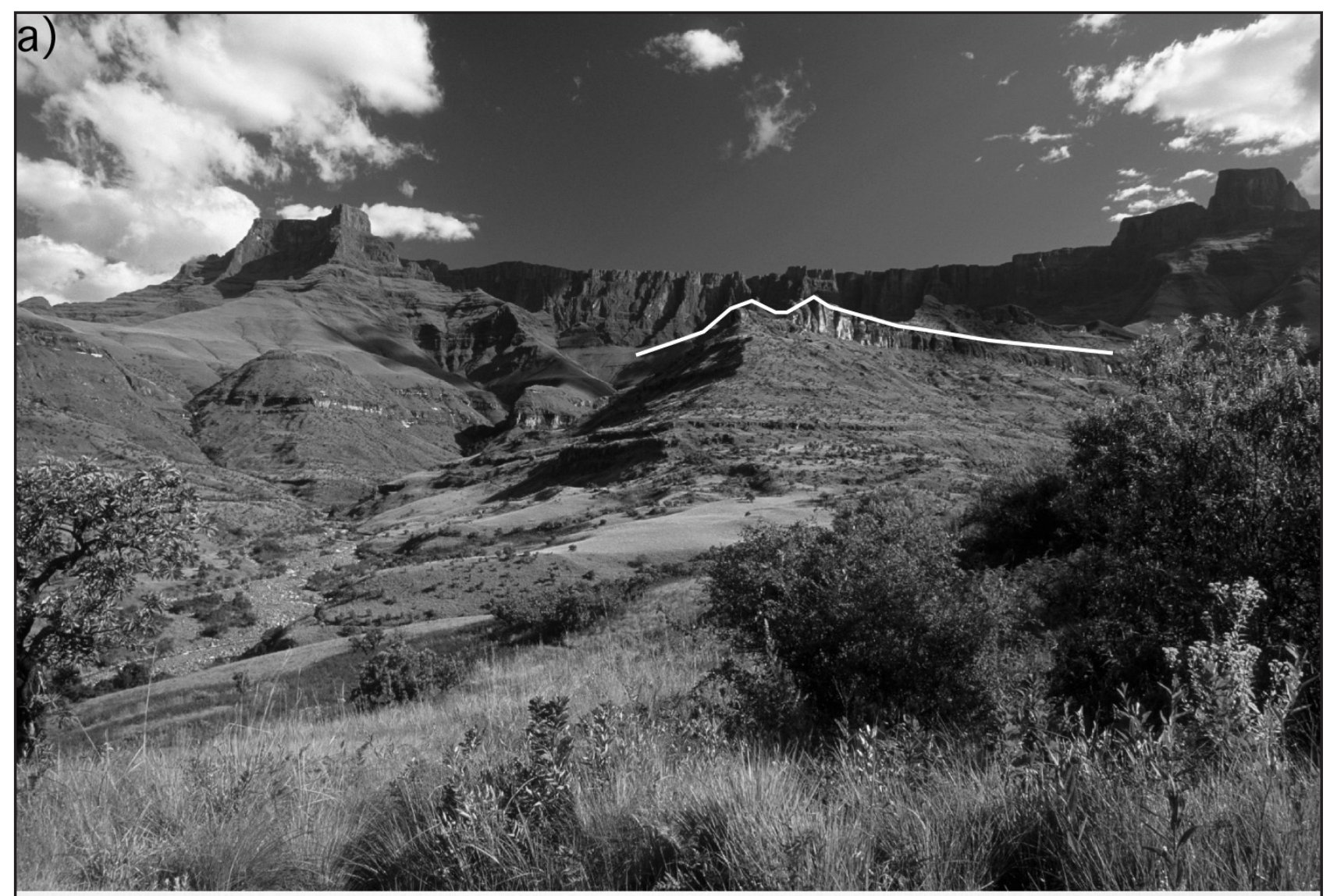

b)

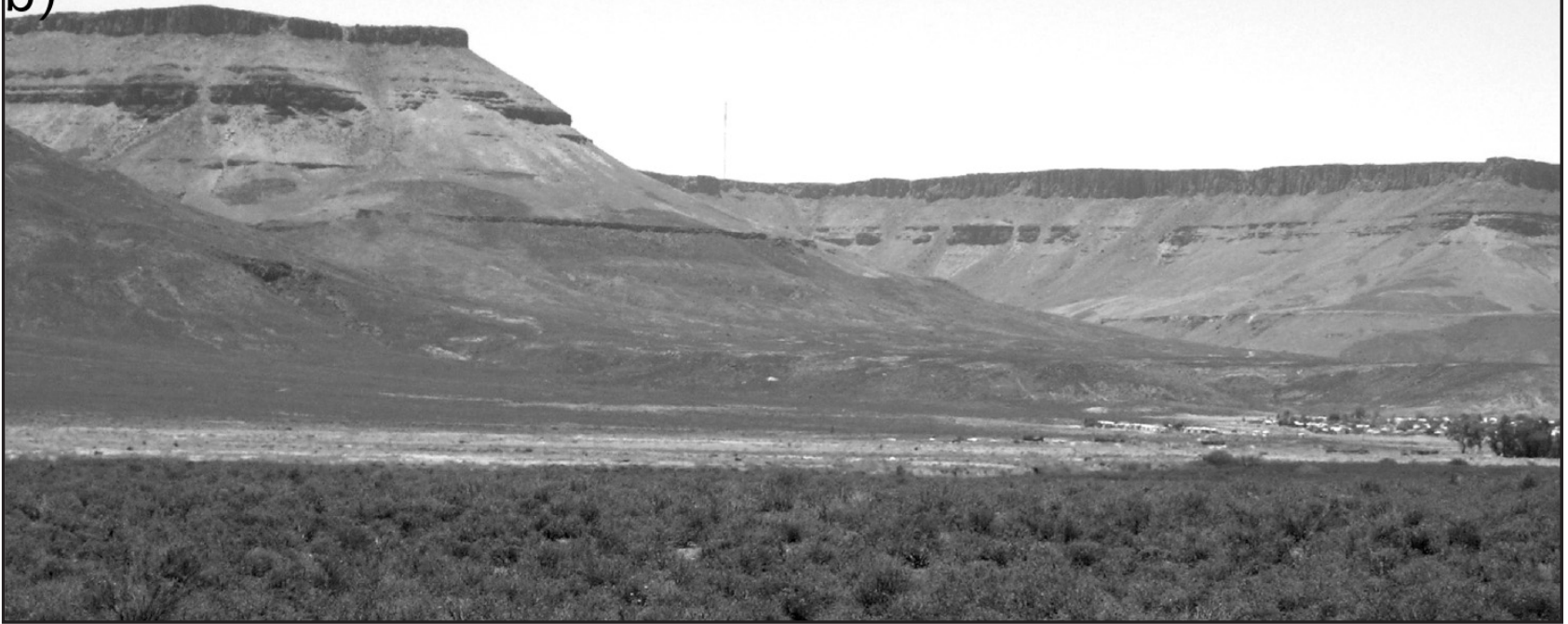

Figure 4. (a) Drakensberg Amphitheatre. Royal Natal national park. Clarens sandstone scarp emphasised by white line. (b) Scarps formed by a massive dolerite sill overlooking the town of Calvinia, Northern Cape, South Africa. Note the well developed vertical cooling joints. Figure 4a may not be reproduced without the express permission of Africa Imagery (http://www.africaimagery.com) 


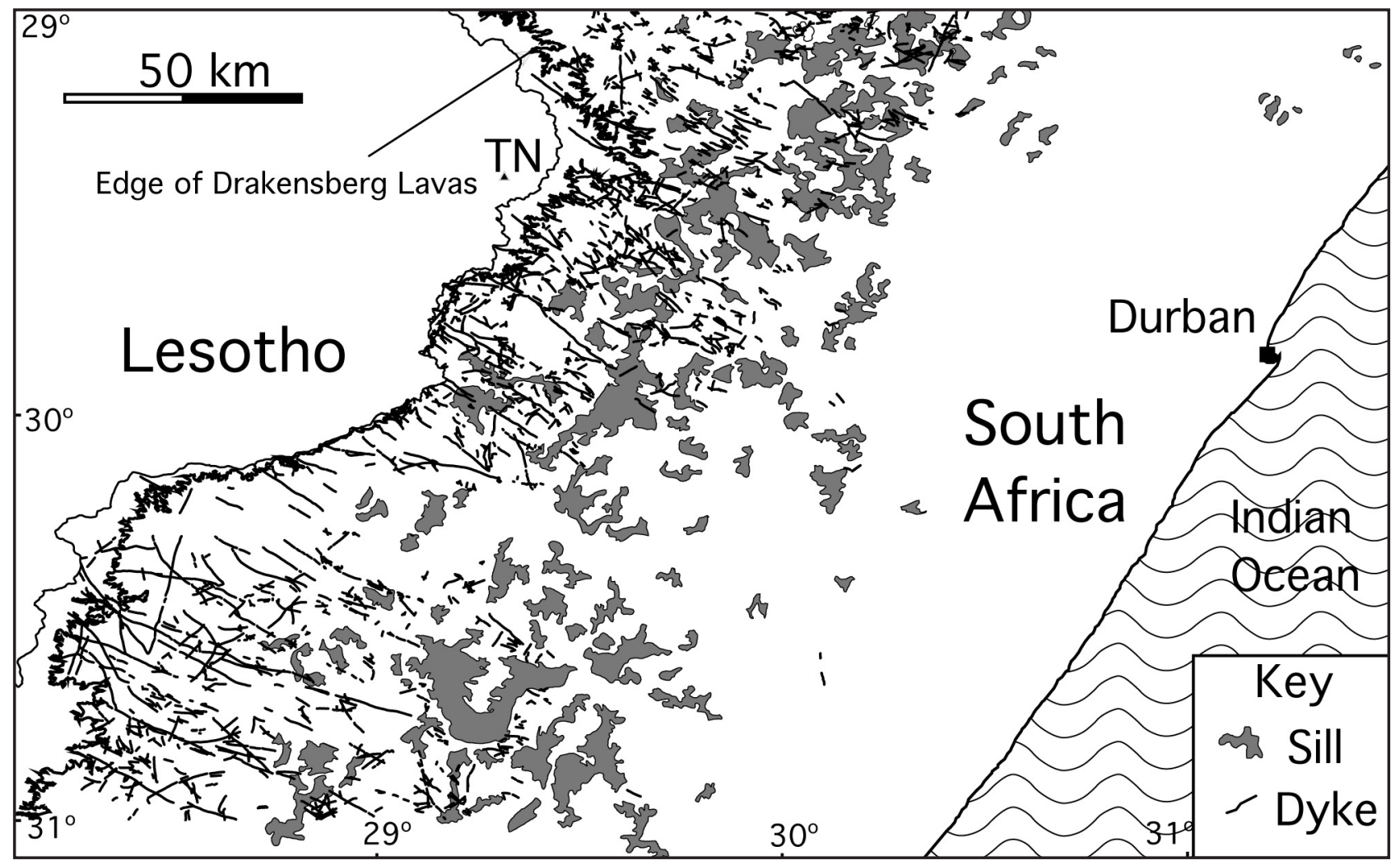

Figure 5. Karoo dykes and sills in the southern Natal, based on Council for Geoscience (1981a; b; 1988a; b). TN - Thabana Ntlenyana. The Drakensberg escarpment corresponds closely to the edge of the basalts.

Cape Town's Table Mountain is the most famous of these. The pervasive scarp topography of southern Africa undoubtedly played a major role in influencing the thinking of King.

Large boulders of massive basalt and Clarens sandstone are invariably present on the scree slopes below the cliffs formed by these resistant lithological units. Indeed, analogous scree slopes characterize all the other major escarpments in the interior of southern Africa. This provides direct field evidence that erosion of the resistant lithologies forming these scarps is controlled primarily by the detachment of large blocks along joints and other lines of weakness by processes such as undercutting and ice-wedging. Back-wearing, and thus scarp retreat, would be an inevitable consequence of this mode of erosion.

\section{Scarp degradation by an inland drainage divide?}

On the basis of numeric surface process modelling calculations, van der Beek et al. (2002) conclude that a marginal scarp formed during continental break-up will degrade rapidly (within $\sim 10 \mathrm{Ma}$ ) if there is a pre-existing inland drainage divide, with a new scarp developing in the vicinity of the watershed several tens of million years after break-up. However, direct field evidence from a number of very widely distributed locations conflicts with this conclusion.

The Victoria Falls (Figure 1) on the Zambezi River (the largest in south-central Africa) forms a dramatic scarp, some $100 \mathrm{~m}$ high, that is capped by three massive lava flows (Wellington, 1955). Since capture of the upper Zambezi by the mid-Zambezi in the early Pleistocene or late Pliocene, there has been over $100 \mathrm{~km}$ of headward erosion to the present position of the Falls (Wellington, 1955; Moore and Larkin, 2001) - almost the same distance as the width of the coastal plain to the east of the Drakensberg escarpment. Yet despite the flow of the largest river of south-central Africa, the massive lavas capping the Victoria Falls have prevented their degradation.

An additional spectacular example of a lithological unit that has resisted degradation by an inland river divide is provided by the Niagara Falls. These have formed where the Niagara River flowed over an extensive escarpment, made up of Silurian sediments with an upper resistant Silurian dolostone capping overlying less competent limestone, shale and sandstone units. Headward advance of the Niagara Falls, over a distance of some $11 \mathrm{~km}$ during the past $\sim 10000$ years (just over $1 \mathrm{~m} /$ year), has proceeded by scarp retreat as a result of undercutting of the massive dolostone capping by erosion of the less resistant underlying lithologies (Tinkler, 1998).

A further pertinent observation is that the long-lived $(\sim 80 \mathrm{Ma})$ escarpment along the eastern Australian seaboard has not degraded, despite the existence of a major drainage divide well inland (Ollier, 1982; 2004, Ollier and Stevens, 1989; Bishop and Goldrick, 2000). Over much of its length, this escarpment is composed of resistant crystalline metasediments (Bishop and 
Goldrick, 2000). Collectively, these observations demonstrate that scarps formed by resistant lithological units will not necessarily degrade when associated with an inland drainage divide.

\section{East coast tectonics}

Partridge and Maud (1987) and Partridge (1998) infer that the east coast of southern Africa experienced mild uplift (200 to $300 \mathrm{~m}$ ) during the Miocene, followed by major uplift (up to $900 \mathrm{~m}$ ) in the Pliocene. They note that the long profiles of major east-draining rivers are convex upward, and suggest that major inflections in these profiles, generally associated with a pronounced downstream increase in grade, mark the line of maximum late Neogene uplift, which they designated the Ciskei-Swaziland (C-S) axis (Figure 1). This inferred axis is located roughly parallel to and some $50-80 \mathrm{~km}$ inland of the east coast and, along the northern sector, is associated with a belt of hot springs (Partridge, 1998). van der Beek et al. (2002) subsequently argued, on the basis of numerical surface process modelling, that the major inflections in river courses could in principle be explained by resistant lithological units, such as dolerite sills intruding the more readily eroded Karoo sediments to the east of the Drakensberg, and called into question the Neogene uplift along the C-S axis inferred by Partridge and Maud (1987) and Partridge (1998).

However, the evidence for late Neogene uplift in the east of southern Africa is unequivocal. Partridge (1988) notes that such uplift is necessary to account for early Pliocene marine sediments at an altitude of $400 \mathrm{~m}$ to the east of Port Elizabeth (Maud and Botha, 2000). Geomorphological characteristics of the east coast drainages also provide clear testimony to the uplift recognized by Partridge (1998). Over most of their lengths, these rivers all follow tortuous meandering courses, typically associated with extreme senility. The upper reaches of these meandering rivers flow in broad basins, but to the east of the C-S axis, they have incised spectacular deep valleys. The Kei river valley (Figure 1), for example, is some $550 \mathrm{~m}$ deep where it is crossed by the N2 highway, only $40 \mathrm{~km}$ from its mouth. These deeply incised meandering rivers clearly reflect a major rejuvenation event, and the obvious candidate is the uplift recognized by Partridge and Maud (1987) and Partridge (1998).

\section{Discussion}

\section{Evolution of the Drakensberg Escarpment}

Massive lava flows of the Drakensberg Formation, and thick dolerite sills of equivalent composition, form major cliffs over a wide geographic area of southern Africa (Figure 1), characterized by a wide range in rainfall. The same is true of the sandstones of the Clarens Formation. The dramatic cliffs formed by these two geological units are thus primarily controlled by lithology.

The underlying lithological control responsible for formation of the dramatic cliffs of the Drakensberg Escarpment does not rule out the possibility that this first order morphological feature is also spatially associated with a pre-existing drainage divide. However, it is clearly not possible to ascribe all of the scarps bounding the Drakensberg to formation at long-lived pinned inland river divides, because of the fundamental asymmetry of this mechanism. It is therefore necessary to examine the observations that have been put forward as objections to the scarp retreat model, and consider possible factors that may account for these observations. These are discussed below.

The rapid phase of denudation at approximately 91 to 69 Ma that Brown et al. (2002) identified from AFTT studies of samples from the Swartberg borebole (Figure 1), located $30 \mathrm{~km}$ seawards of the escarpment, cannot be reconciled with a uniform rate of retreat, since approximately $130 \mathrm{Ma}$, of a scarp originally located close to the coast (i.e. some $120 \mathrm{~km}$ to the east of the borebole.) Brown et al. (2002) and van der Beek et al. (2002) note that this objection would fall away if there was a rapid reduction of the rate of scarp retreat after approximately 91 to $69 \mathrm{Ma}$. However, they question whether and how a change in climate, as advanced by Partridge and Maud (1987) and Partridge (1998), could produce a change in erosion rates of sufficient magnitude. We draw attention to lithological controls that played a major role in decreasing erosion rates during the Cenozoic, and then review subordinate complementary factors, including possible climatic influences.

Individual lava flows from continental flood basalts are capable of travelling several 100's of $\mathrm{km}$ (e.g. Cashman et al., 1998), even as far as $500 \mathrm{~km}$ (Ho and Cashman, 1997). It is therefore very likely that the Karoo basalts originally extended well beyond the modern outcrop, and arguably formed a carapace covering virtually all of southern Africa. Evidence to support this comes from the occurrence of basalt xenoliths in kimberlite pipes located some $300 \mathrm{~km}$ to the west of the main Drakensberg outcrop (Hawthorne, 1975). At the time of disruption of Gondwana, initial erosion therefore likely involved dissection of this lava carapace. A capping of massive basalts likely extended some distance coastwards of the present-day outcrop of the Drakensberg. Particularly massive lava flows would be anticipated close to or within the dense dyke box work surrounding the present lava outcrop (Figure 5).

If rifting produced an uplifted scarp shoulder close to the coast, the question of whether this feature would survive degradation by a hypothetical inland drainage divide depends on the resistance to erosion of the basalt capping (which is represented by the unconstrained mathematical constant $\mathrm{L}_{\mathrm{f}}$ required in the theory used in surface process models). This would in part be related to climate, but there are unfortunately scant data for climatic changes for the area to the east of the Drakensberg escarpment. $\mathrm{L}_{\mathrm{f}}$ would also be a function of the thickness of lavas capping the basalt, or interbedded flows within the lava pile. 
The thickness of individual lava flows close to the coast is entirely conjectural. However, if sufficiently massive, the field evidence discussed suggests that degradation of the scarp may not occur. The resistant Cave sandstone underlying the lavas would maintain the integrity of any initial scarp. Rapid erosion accompanying initial break-up would accordingly be expected to result in scarp retreat. The resultant isostatic unloading, and linked uplift of the retreating scarp, would in turn lead to coincidence of the scarp and drainage divide (Gilchrist and Summerfield, 1990; 1991; Bishop and Goldrick, 2002), irrespective of their original relative locations. Even if an initial coastal escarpment was rapidly degraded by an inland drainage divide (still an open question), a new escarpment might be expected to form when massive lava flows were subsequently encountered - most likely close to the eastern edge of the dyke network shown in Figure 5. Regardless of where the escarpment initially formed, the armouring effect of a carapace of such massive lava flows should result in a dramatic decrease in the rate of erosion. This reduction could in part account for the slow scarp retreat over the $30 \mathrm{~km}$ from the Swartberg borehole to the modern escarpment since approximately 91 to $69 \mathrm{Ma}$.

\section{Climatic controls on erosion rates}

The suggestion that climatic deterioration provides an explanation for slow rates of erosion since the midCretaceous (Partridge and Maud, 1987; Partridge, 1998) has been dismissed by Brown et al. (2002) on the basis that "it is difficult to envisage a significant change in morphoclimatic regime between the Cretaceous and Cenozoic that could account for a reduction in retreat rate by nearly an order of magnitude". Whether this opinion is warranted is a matter of debate. Climate clearly plays a major role in influencing the depth of weathering. Thus there is shallow or negligible regolith over crystalline basement in arid areas such as the Bushmanland-Namaqualand area of north-west South Africa. In contrast, in Madagascar - where the central highlands and east coast experience a tropical climate, with annual rainfall ranging from 1000 to over $2000 \mathrm{~mm}$ (www.explore.co.uk/weather_country/WWG01090htm), there is a pervasive, thick laterite-saprolite capping, ranging from tens to hundreds of metres in thickness, and the country is aptly dubbed "the red island". This carapace is readily eroded, particularly in areas where poor land-use has degraded the grass cover. However, the link between the depth of weathering and erosion rates is more complex, as increasing precipitation leads to more luxurious vegetation, which protects the regolith. Certainly, erosion rates increase significantly where overgrazing or other poor land-use practise has degraded grasslands. In Madagascar, high modern rates of erosion, linked to degradation of the grass cover are reflected in the muddy, sluggish rivers flowing in broad sediment-choked flood-plains, particularly in the west of the country where gradients are low. The importance of vegetation in controlling erosion rates is considered in greater detail in a later section.

A further problem in evaluating the importance of climate in controlling rates of Drakensberg scarp retreat is the paucity of evidence for detailed climatic variation in the critical area immediately to the east of the escarpment. Much of the evidence for CretaceousCenozoic climatic change in southern Africa is from kimberlites and fluvial sediments in the north-west of South Africa (e.g. de Wit and Bamford, 1993). While this portion of the country presently experiences very arid conditions $(<250 \mathrm{~mm}$ annual rainfall), precipitation in the area immediately east of the Drakensberg escarpment is in excess of $1000 \mathrm{~mm}$. The potential magnitude of climate change in the latter area during times of higher precipitation in the northwest of the country is not constrained.

It is also difficult to assess quantitatively the relative importance of climate and lithology in controlling erosion rates. However, given the field evidence for the importance of lithology in forming major scarps in southern Africa, our view is that this is the dominant control on escarpment retreat rates. Strong support for this conclusion comes from the coastal plain of eastern Madagascar where, despite the tropical climate, high rainfall and deep laterite/saprolite development, apatite fission track evidence (Emmel et al., 2004; Seaward et al., 2004) points to very limited erosion since the midCretaceous separation of the island from India (de Wit, 2003). This contrasts with the high early-Cretaceous erosion rates in the west of southern Africa subsequent to separation of Africa and South America, involving the removal of significant thicknesses of readily eroded Karoo sediments.

Equivalents of the latter rocks presently occur along the western seaboard of Madagascar (de Wit, 2003), but were absent or of negligible thickness on the eastern coastal plain (Seaward et al., 2004), which is underlain by crystalline rocks (de Wit, 2003). The AFT data of Seaward et al. (2004) and Emmel et al. (2004) thus provide strong evidence that the crystalline basement along the eastern seaboard resisted erosion even under the prevailing tropical, high rainfall $(>2000 \mathrm{~mm}$ annually) climatic regime. In short, lithology is the overriding control on rates of erosion, and climate a subordinate factor.

A further, though somewhat speculative, factor may have contributed to slow erosion rates since the mid-late Cretaceous. This period is broadly coeval with the major radiation of the Angiosperms (flowering plants) (Burgoyne et al., 2005). A noteworthy component of this major group are the Restionacaea (or reeds), which are today an important element of the "fynbos" biome - the group of plants that have adapted to acid, nutrient-poor soils of the quartzite mountains of the southwestern and southern Cape in South Africa. Restionaceae pollen is first recorded in southern Africa in crater sediments of the late Cretaceous kimberlite pipes of the Bushmanland-Namaqualand area in the northwest of 
South Africa (Scholz, 1985). The family is thus a relatively early-evolving Angiosperm representative. Many of the modern Restionacea have rhizomes (laterally growing underground rooting stems), and in the Cape mountains, this group of plants often occurs as very dense stands that dominate the mountain vegetation (Haaksma and Linder, 2000). The evolution of this family could therefore have played a significant role in binding the soil, and reducing erosion rates in such mountainous areas.

\section{Cosmogenic isotopes suggest very slow recent (last $10^{4}$ to $10^{6}$ years) rates of scarp retreat (Fleming et al., 1999)}

Two factors, likely complementary, could reinforce the dominant lithological controls we invoke to account for the slow recent rates of scarp retreat of the eastern Drakensberg reported by Fleming et al. (1999). Firstly, while late Neogene uplift parallel to the east coast has resulted in rapid erosion, and deep river incision, on the coastal side of the C-S axis, the associated lowering of gradients inland of the axis would result in a marked decrease in erosion rates. It might be argued, following van der Beek et al. (2002), that the low gradients of the upper reaches of the east coast rivers are lithologically related, and merely reflect exposure by erosion of massive dolerite sills. While detailed field studies would be required to test this alternative interpretation, the practical result would be the same - a marked decrease in erosion rates. The marked decrease in river gradients inland of the C-S axis, irrespective of their origin, would thus contribute to the extremely slow present-day rates of retreat of the Drakensberg escarpment inferred from the cosmogenic isotope studies.

Slow modern retreat rates of the Drakensberg escarpment may have also been influenced by a major development in plant evolution. The expansion of widespread tropical savanna type grasslands, characterized by the $\mathrm{C}_{4}$ photosynthetic pathway (Sage, 2004), is now recognized to have taken place relatively recently. Because of the paucity of fossil evidence, the timing of this ecologically important event is not precisely constrained. Cerling (1992) suggests that the proportion of $\mathrm{C}_{4}$ grassland increased in the Pliocene and Pleistocene, but that the development of virtually pure $\mathrm{C}_{4}$ vegetation stands only occurred in the midPleistocene. Jacobs (2004) envisages that this vegetation type became dominant at a somewhat earlier time, with the grass-dominated savanna biome expanding in the middle Miocene (16 Ma), and becoming widespread by the Late Miocene $(\sim 8 \mathrm{Ma})$.

While the Restionacaea today are typically montane species (Haaksma and Linder, 2000), the C4 grasses occur over a wide range of altitude and habitats. They dominate the lower slopes of the Drakensberg (Scott, 2002), and may well have displaced the Restionacaea, which now form a very subordinate component of the vegetation in this mountainland.
The evolution of widespread $\mathrm{C}_{4}$ grasses thus may have had a major influence in reducing erosion rates across the entire landscape. This major biological event may thus be a contributing factor to the slow modern rates of retreat of the Drakensberg scarp identified by Fleming et al. (1999).

Several lines of evidence demonstrate a coincidence between the evolution of the $\mathrm{C} 4$ grasses and a dramatic recent change in erosion rates. In southern Africa, there was a significant decrease in sediment supply to the west coast depocentres during the Neogene (Rust and Summerfield, 1990). However, there has been an increase in historically recent rates, which has been ascribed to poor farming practise (overgrazing of grasslands) (Dingle and Hendy, 1984). Certainly, overgrazing of grasslands is a major contributor to the present-day increase in erosion rates in southern Africa, and indeed elsewhere in the world.

Further, supporting evidence comes from the Great Escarpment of eastern Australia. Ollier (1982) describes an essentially uneroded 3 Ma valley-fill lava that flows across the escarpment near Innisfail in Queensland. However, erosion of the escarpment has cut lava flows dated at $20 \mathrm{Ma}$ at Toowoomba (Queensland) (Ollier and Stevens, 1989) and also the 19 Ma Ebor volcano in New South Wales (Ollier, 2004). The ages of the young uneroded lavas post-date the major expansion of the $\mathrm{C}_{4}$ grasses recognized by Jacobs (2004), while the older eroded volcanoes pre-date this grassland expansion. Clearly, detailed field studies are needed at these different localities to determine whether there may be other factors that may have influenced erosion rates. However, the relationships are consistent with the suggestion that the evolution of extensive $\mathrm{C}_{4}$ grasslands had a significant effect on modern erosion rates.

In summary, field evidence points to lithological controls as the dominant factor controlling rates of retreat of the Drakensberg Escarpment, with erosion rates decreasing rapidly when massive flows were encountered near the margins of the dyke boxwork surrounding the Karoo lavas. This primary lithological control may have been compounded by the subordinate effects of the trend towards a more arid climate after the mid-Cretaceous, the late Cretaceous evolution of the Restionacaea, Neogene uplift along the C-S axis (Partridge, 1998), and the influence of the evolution of the $\mathrm{C}_{4}$ grasses in the late Neogene. The relative importance of these subordinate factors is difficult to assess quantitatively at present, however.

A study of sediment rates along the Transkei to southern Natal coast, to the east of the Drakensberg, should provide an independent test for the proposal that there has been a dramatic decrease in erosion rates since the late-Cretaceous. The main depocentre in this area is the south-west oriented Natal Basin (Figure 1; Dingle et al., 1983). The stretch of coast where rivers draining the eastern Drakensberg scarp empty into the Indian Ocean is separated from the Natal basin by a prominent 
arch (the Transkei Arch) (Figure 1; Dingle et al., 1983), and sedimentation rates are poorly established for this section of the basin. In addition, sediment supply is strongly influenced by current dispersion from the Tugela cone (Figure 1), in the north of the Natal Valley. Although the western headwaters of the Tugela rise off the northeast scarp of the Drakensberg, the main catchment drains a large hinterland well to the east of these mountains. A further problem is that the detailed history of evolution of the Tugela River system is not well known. The available information on sedimentation rates for the Tugela cone indicates a generalized decrease in sediment supply from the upper Cretaceous (Maastrichtian) through the Palaeogene to the Oligocene (Dingle et al., 1983). While it is not clear whether these trends reflect rates of erosion on the Drakensberg escarpment, they are at least consistent with decreasing rates of scarp retreat after the end of the Cretaceous.

It is implicit in the processes proposed in this study that accelerated rates of erosion have occurred coastwards of the C-S axis, as reflected by the deeply incised meanders to the east (coastal side) of the axis. Dingle et al. (1983) note that there was a dramatic increase in sedimentation rates in the Tugela cone during the Miocene-Pliocene (late Neogene), although they were unable to account for this change. This observation is however consistent with Pliocene uplift along the C-S axis, and rejuvenation of the rivers on the coastal side of the axis, resulting in their deeply incised modern courses. Uplift associated with this axis may have overridden any moderating effect of the evolution of the $\mathrm{C}_{4}$ grasses to the east of the C-S axis. The geomorphological evidence discussed earlier, coupled with the sedimentary evidence from the Tugela cone, thus provide compelling further support for an axis of Neogene uplift in the east of the sub-continent, as recognized by Partridge (1988).

\section{Geophysical modelling points to the existence of a drainage divide located some $150 \mathrm{~km}$ inland at the time of breakup (Brown et al., 2002)}

As noted by Brown et al. (2002), the model used to infer an inland drainage divide does not take into account any transient tectonic component of uplift related to rifting or mantle plumes. Cox (1989) has indeed suggested that such mantle plumes provided a first order control on the post-Gondwana drainage system of southern Africa. The Cox model received recent support from Moore and Blenkinsop (2002), who highlighted the marked change in drainage patterns on the sub-continent associated with the disruption of Gondwana. These drainage patterns are not readily reconciled with the putative inland drainage divide at the time of rifting, inferred only on the basis of geophysical modelling. The geological field and other evidence presented is consistent with the earlier proposals of King $(1963 ; 1972)$ for the importance of scarp retreat in the formation of the modern Drakensberg escarpment. Scarp retreat also provides a more satisfactory explanation for the episode of accelerated denudation recognized from the study of the Swartberg borehole (Brown et al., 2002) than progressive surface lowering.

Nevertheless, it is possible that evolution of the Drakensberg may have involved the interplay of the extreme models envisaged by King (scarp retreat) on the one hand, and Brown et al. (2002) and van der Beek et al. (2002) (influence of an inland drainage divide), on the other. Thus rivers rising off an inland divide could have resulted in the degradation of an initial escarpment close to the coast if this was capped by thin lava flows. Thereafter, following rapid erosion, a new escarpment developed when thick lava flows were exhumed, likely in the proximity of the eastern edge of the dense dyke boxwork illustrated in Figure 5. However, a counterargument is that the integrity of an escarpment close to the coast would have been underpinned by exposure of the resistant Clarens Formation, and that isostatic uplift associated with scarp retreat, as modelled by Gilchrist and Summerfield (1990; 1991), is responsible for a coincidence of the escarpment and drainage divide.

In conclusion, field evidence shows that major scarps in southern Africa are above all lithologically controlled. The development of the Drakensberg section of the Great Escarpment, and slow Cenozoic rates of retreat, are primarily linked to the armouring effect of the resistant capping formed by massive lava flows, and underlying massive Clarens Formation sandstones. It seems reasonable to postulate that persistence of the Eastern Australian escarpment, despite the long-term existence of an inland drainage divide, is related primarily to the resistant crystalline rocks that form this escarpment. An inland drainage divide cannot be ruled out entirely as a subordinate factor in the evolution of escarpment. However, the importance of this process remains speculative at best, because of a lack of direct field evidence and the large number of unconstrained variables in the numeric surface models that underpin this interpretation.

\section{Multiple Erosion Cycles in southern Africa}

The existence in southern Africa of discrete surfaces related to multiple erosion cycles has been strongly challenged on the basis of numerical surface process modelling (e.g. Gilchrist and Summerfield, 1990; 1991; Brown et al., 2002; van der Beek et al., 2002). However, direct field evidence for multiple erosional events on the eastern coastal plain of southern Africa is overwhelming. The oldest of these cycles is represented by an undulating surface of low relief, planed across steeply dipping Devonian-Permian sediments of the Cape and Karoo Supergroups, leaving no doubt that this is an erosional feature. This peneplain is particularly well developed in the Grahamstown area of the Eastern Cape (Figure 1), where it has the thick kaolinized capping, associated with silcretes typical of the African Surface (Partridge and Maud, 1987). Marker and McFarlane (1997) present evidence to suggest that this surface reflects more than one erosion cycle. 
The well-developed meanders in the east-flowing rivers draining the escarpment are characteristic of mature landscapes. The African surface is not preserved on either the river floor or interfluves, indicating that they developed on a post-African surface. The deeply incised courses of these rivers coastwards of the C-S axis testify to rejuvenation of this mature landscape and initiation of a new cycle of erosion. There is therefore no question that the eastern coastal margin of southern Africa has experienced at least two and likely three discrete cycles of erosion.

One of the major criticisms levelled at models for multicyclic landscape evolution in southern Africa has been the lack of a satisfactory tectonic mechanism to account for initiation of a new cycle of erosion. Thus, Gilchrist and Summerfield (1990; 1991) argued against multiple erosion cycles in southern Africa primarily on the basis of their rejection of the mechanism proposed by King to account for their origin. Uplift along the C-S axis, recognized by Partridge (1998) provides at least one trigger for initiating a new cycle of erosion along the south and east coastal plain of southern Africa. Clearly, an important aspect to address in terms of understanding the origin of multiple erosion cycles is the driving force behind the uplift along the C-S axis. On the very largest scale, the influence of dynamic topography may be important (e.g. Lithgow-Bertelloni and Silver, 1998).

\section{Implications for numeric surface process modelling}

Numeric surface modelling of the evolution of the Drakensberg (Van der Beek et al., 2002) leads to the conclusion that scarps will degrade where there is an inland drainage divide. This finding is at odds with several lines of field evidence presented earlier, such as the integrity of the Victoria and Niagara Falls, and the eastern Australian escarpment. One possible explanation of this discrepancy is that inappropriate variables were used in the surface process models. Finding a way to constrain quantitatively surface process model parameter values is essential if such models are to predict quantitatively long-term denudation rates in, and sediment supply from, specific regions (van der Beek and Braun, 1998). Geological field evidence shows convincingly that scarps in southern Africa are primarily related to the presence of resistant cap rocks (quartzites, massive lavas and dolomites). This in turn requires that surface process models involving such lithologies will produce spurious results unless variables such as $\mathrm{L}_{\mathrm{f}}$ are of minimum magnitude to require the development of a scarp when these geological units are exposed. If the temporal association between vegetation evolution and erosion rates pointed out above reflects a causative link, surface process models also need to address this aspect of landscape evolution.

\section{Conclusions}

The Drakensberg - Maluti mountainland is surrounded on all sides by double escarpments. Karoo-aged lavas and dolerites, and resistant sandstone units over a wide region of southern Africa also form prominent escarpments. Examples of escarpments surviving for long periods, despite the existence of inland drainage divides, occur in southern Africa and elsewhere in the world.

These observations demonstrate that resistant lithological units are a dominant factor in escarpment evolution. Numerical surface process models that predict rapid degradation of escarpments and their re-establishment near the position of an inland drainage divide are not appropriate in several cases, including the Drakensberg escarpment. These models do not account for the observation that the Drakensberg-Maluti mountainland does not have a single escarpment facing the breakup axis, but instead is surrounded by escarpments, including one that is perpendicular to the putative inland drainage divide. This observation suggests that any role played by an inland drainage divide in escarpment evolution must be more complex than demonstrated by the models. The existence of inland facing scarps on the Drakensberg-Maluti mountains also suggests that escarpment formation around the mountainland is not exclusively related to processes that occur at or adjacent to the site of continental break-up.

\section{Acknowledgements}

This manuscript benefited considerably from constructive critical comments made by the two referees (Tim Partridge and John Compton). Their input is gratefully acknowledged. We are grateful to Roger de la Harpe for permission to use the photograph in Figure 4a.

\section{References}

Bishop, P. and Goldrick, G. (2000). Geomorphological evolution of the East Australian continental margin. In: M.A. Summerfield (Editor), Geomorphology and global tectonics, John Wiley \& Son, New York, United States of America, 225-254.

Braun, J. and Sambridge, M. (1997). Modelling landscape evolution on geological time scales: A new method based on irregular spatial discretization, Basin Research, 9, 27-52.

Brown, R.W., Summerfield, M.A. and Gleadow, A. J.W. (2002). Denudational history along a transect across the Drakensberg Escarpment of southern Africa derived from apatite fission track thermochronology. Journal of Geophysical Research, 107, (B12) 2350 , doi:10.1029/2001JB000745.

Burgoyne, P.M., van Wyk, A.E., Anderson, J.M. and Schrire, B.D. (2005). Phanerozoic evolution of plants on the African plate. Journal of African Earth Sciences, 43, 13-52.

Cabutt, C. and Edwards, T. (2002). Cape elements on high-altitude corridors and edaphic islands: historical aspects and preliminary phytogeography. Systematics and Geography of Plants 71, 1033-1066.

Cashman, K.V., Pinkerton, H. and Stephenson, J. (1998). Long lava flows. Journal of Geophysical Research, 103, 27281-27289.

Cerling, T.E. (1992). Development of grasslands and savannas in East Africa during the Neogene. Palaeogeography, Palaeoclimatology Palaeoecology, 97, 241-247.

Cockburn, H.A.P., Brown, R.W., Summerfield, M.A., and Seidl, M.A. (2000). Quantifying passive margin denudation and landscape development using a combined fission-track thermochronology and cosmogenic isotope analysis approach. Earth and Planetary Science Letters, 179, 429-435. 
Council For Geoscience. (1981a). 1: 250000 Geological Series Sheet 2928 (Drakensberg). Government Printer, Pretoria.

Council for Geoscience. (1981b). 1: 250000 Geological Series Sheet 3028 (Kokstad). Government Printer, Pretoria.

Council for Geoscience. (1988a). 1: 250000 Geological Series Sheet 2930 (Durban). Government Printer, Pretoria.

Council for Geoscience. (1988b). 1: 250000 Geological Series Sheet 3030 (Port Shepstone). Government Printer, Pretoria.

Council for Geoscience. (1997). Geological map of the Republic of South Africa, 1: 1000000 scale. Government Printer, Pretoria.

Cox, K.G. (1989). The role of mantle plumes in the development of continental drainage patterns. Nature, 342, 873-877.

Dempster, A.N. and Richard, R. (1973). Regional geology and structure. In: P.H. Nixon (Editor), Lesotho Kimberlites. Cape and Transvaal Printers, Cape Town, South Africa, 1-19.

De Wit, M.C.J. (1999). Post-Gondwana drainage and the development of inland alluvial diamond deposits in South Africa. Economic Geology, 94, 721-740

De Wit, M.C.J. and Bamford, M.K. (1993). Fossil wood from the Brandvlei area as an indicator of palaeoenvironmental changes during the Cenozoic. Palaeontologia africana, 30, 81-89.

De Wit, M.J. (2003). Madagascar: Heads it's a continent, tails it's an island Annual Reviews of Earth Sciences, 31, 213-48.

Dingle, R.V. and Hendy, Q.B. (1984). Late Mesozoic and Tertiary sediment supply to the eastern Cape basin (Southeast Atlantic) and Palaeo-drainage systems in southwestern Africa. Marine Geology, 56, 13-26.

Dingle, R.V., Siesser, W.G. and Newton, A.R. (1983). Mesozoic and Tertiary geology of southern Africa. A.A. Balkema, Rotterdam, The Netherlands, $375 \mathrm{pp}$.

Emmel, B., Jakobs, J. and Razakamanana, T. (2004). Titanite and apatite fission track analyses on basement rocks of central-southern Madagascar: constraints on exhumation and denudation rates along the eastern rift shoulder of the Morondava basin. Journal of African Earth Sciences, 8, 343-361.

Erlank, A.J., Marsh, J.S., Duncan, A.R., Miller, R. McG., Hawkesworth, C.J., Betton, P.J. and Rex, D.C. (1984). Geochemistry and petrogenesis of the Etendeka volcanic rocks from South West Africa/Namibia. Special Publication of the Geological Society of South Africa, 195-246.

Fleming, A., Summerfield, M.A., Stone, J.O., Fifield, L.K. and Cresswell, R.G. (1999). Denudation rates for the southern Drakensberg escarpment, SE Africa, derived from in-situ-produced cosmogenic ${ }^{36} \mathrm{Cl}$ : initial results. Journal of the Geological Society of London, 156, 209-212.

Fullard, H. and Darby, H.C. (1974). The University Atlas (16th edition) George Philip and Son. Limited, London, United Kingdom, 176pp.

Gilchrist, A.R. and Summerfield, M.A. (1990). Differential denudation and flexural isostacy in formation of rift-margin upwarps. Nature, 346, 739-742.

Gilchrist, A.R. and Summerfield, M.A. (1991). Denudation, isostacy and landscape evolution. Earth Surfaces Processes and Landforms, 16, 555-562.

Haaksma, E.D. and Linder, H.P. (2000). Restios of the fynbos. Botanical Society of South Africa, 188pp.

Hawthorne, J.B. (1975). Model of a kimberlite pipe. In: L.H. Ahrens, J.B. Dawson, A.R. Duncan and A.J. Erlank (Editors). Physics and Chemistry of the Earth, 9, 1-16.

Ho, A. and Cashman, K.V. (1997). Temperature constraints on a flow of the Columbia River Basalt Group. Geology, 25, 403-406.

Jacobs, B.F. (2004). Palaeobotanical studies from tropical Africa: relevance to the evolution of forest, woodland and savannah biomes. Philosophical Transactions of the Royal Society of London, B359, 1573-1583.

King, L.C. (1955). Pedeplanation and isostacy: an example from South Africa. Quarterly Journal of the Geological Society, 111, 353-359.

King, L.C. (1963). South African Scenery. Oliver and Boyd, London, United Kingdom, 308pp.

King, L.C. (1972). The Natal monocline: explaining the origin and scenery of Natal, South Africa. Geology Department, University of Natal, South Africa, $113 \mathrm{pp}$.

Kooi, H. and Beaumont G. (1994). Escarpment evolution on high-elevation rifted margins: insights derived from a surface process model that combines diffusion, advection and reaction. Journal of Geophysical Research, 99, 12191-12209.

Lithgow-Bertelloni, C, and Silver, P.G. (1998). Dynamic topography, plate driving forces and the Africa Superswell, Nature, 395, 269-272.

Marker, M.E and McFarlane, M.J. (1997). Cartographic analysis of the African Surface complex between Albertinia and Mossel Bay, southern Cape, South Africa. South African Journal of Geology, 100, 185-194.

Marsh, J.S., Hooper, P.R., Rehacek, J., Duncan, R.A. and Duncan, A.R. (1997). Stratigraphy and Age of Karoo Basalts of Lesotho and Implications for correlations within the Karoo Igneous Province. American Geophysical Union Geophysical Monograph, 100, 247-272.

Matmon, A., Bierman, P. and Enzel, Y. (2002) Pattern and tempo of great escarpment erosion. Geology, 30, 1135-1138.

Maud, R.R. and Botha, G.A. (2000). Deposits of the south eastern and south coasts. In: T.C. Partridge and R.R. Maud (Editors.). The Cenozoic of southern Africa. Oxford Monographs in Geology and Geophysics, 40, 19-32. Moore, A.M. and Blenkinsop, T. G. (2002). The role of mantle plumes in the development of continental-scale drainage patters: the southern African example revisited. South African Journal of Geology, 105, 353-360.

Moore, A.E and Larkin, P.A (2001). Drainage evolution in south-central Africa since the break-up of Gondwana. South African Journal of Geology, 104, $47-68$.

Ollier, C.D. (1982). The Great Escarpment of eastern Australia: tectonic and geomorphic significance. Journal of the Geological Society of Australia, 29, 13-23.

Ollier, C.D. (2004) The evolution of mountains on passive continental margins. In: P.N. Owens and O. Slaymaker (Editors), Mountain geomorphology Edward Arnold, London, United Kingdom, 59-88.

Ollier, C.D. and Marker, M.E. (1985). The Great Escarpment of southern Africa. Zeitung für Geomorphologie, 54, 37-56.

Ollier, C.D. and Stevens, N.C. (1989). The Great Escarpment of Queensland. In: R.W. Le Maitre (Editor). Pathways in Geology - Essays in honour of Edwin Sherbon Hills. Blackwells Scientific, Melbourne, Australia, 140-152. Partridge, T.C. (1998). Of diamonds, dinosaurs and diastrophism: 150 million years of landscape evolution in southern Africa. 25th Alex du Toit Memorial Lecture. South African Journal of Geology, 101, 165-184.

Partridge, T.C. and Maud, R.R. (1987). Geomorphic evolution of southern Africa since the Mesozoic. South African Journal of Geology, 90, 179-208. Rust, D.J and Summerfield, M.A. (1990). Isopach and borehole data as indicators of rifted margin evolution in southwestern Africa. Marine and Petroleum Geology, 7, 277-287.

Sage, R.F. (2004). The evolution of $\mathrm{C}_{4}$ photosynthesis. New Phytologist, 161, 341-370.

Scholz, A. (1985). The palynology of the upper lacustrine sediments of the Arnot pipe, Banke, Namaqualand. Annals of the South African Museum, 95.1, 1-109.

Scott, Louis (2002). Grassland development under glacial and interglacial conditions in southern Africa: review of pollen, phytolith and isotope evidence. Palaeogeography, Palaeoclimatology Palaeoecology, 177, 47-57. Seaward, D., Grujie, D. and Schreurs, G. (2004). An insight into the breakup of Gondwana: identifying events through low-temperature thermochronology from the basement rocks of Madagascar. Tectonophysics, 23, TC3007,doi:10.1029/2003TC001556,2004.

Tinkler, Keith. (1998). History of Geology Field Trip to Niagara Falls. Geological Society of America Annual Meeting, Toronto, Canada. Field Trip Guide, 9, 20pp.

van der Beek, P. and Braun, J. (1999). Controls on post mid-Cretaceous landscape evolution in the southeastern highlands of Australia: Insights from numerical surface process models. Journal of Geophysical Research, 104, 4945-4966.

Van der Beek, P., Summerfield, M.A., Braun, J., Brown, R. W. and Fleming, A. (2002). Modelling post breakup landscape development and denudational history across the southeastern African (Drakensberg Escarpment) margin. Journal of Geophysical Research, 107, B12 DOI 10.1029/2001JB000744.

Visser, D.J.L. (1989). The geology of the republics of South Africa, Transkei, Bophuthatswana, Venda, Ciskei and the Kingdoms of Lesotho and Swaziland. Explanation: Geological Map (1:1 000 000). Geological Survey, Republic of South Africa, 491pp.

Wellington, J.H. (1955). South Africa - a geographic study. Volume. 1, Physical Geography. Cambridge University Press, United Kingdom, 528pp.

Editorial handling: J. M. Barton Jr. 